\title{
The Apostle Paul in Spinoza and Badiou
}

\author{
Paul A. Rodriguez \\ Philosophy and Religious Studies Department \\ Chaffey College
}

\begin{abstract}
:
This paper offers an analysis of the philosophical interpretations of the apostle Paul in Spinoza's Tractatus Theologico-Politicus (1669) and Badiou's Saint Paul: La foundation de l'universalisme (1997). In addition, a brief description is offered on the difference between, on the one hand, the theological Paul, the Apostle of Faith, and, on the other hand, the historical Paul. Both Spinoza and Badiou offer complex philosophical readings of Paul that can be better understood when taking into consideration how they square with the image of Paul that has been constructed by the various theological traditions of Europe (i.e., the theological Paul), as well as the figure of Paul that is currently being reconstructed by historical-critical biblical scholarship (both New Perspective on Paul and postcolonial/empire-critical readings of Paul).
\end{abstract}

Keywords: Apostle Paul, Benedict Spinoza, Alain Badiou, Political Philosophy, Self 
The aim of the present essay is to discuss the philosophical interpretations of the apostle Paul that can be found in two philosophical masterpieces that are separated by over three hundred years - namely, Benedict de Spinoza's Tractatus Theologico-Politicus (1669) and Alain Badiou's Saint Paul: La foundation de l'universalisme (1997). ${ }^{1}$ Prior to treating the philosophical uses of Paul by Spinoza and Badiou, a brief description is offered on the difference between, on the one hand, the theological Paul, the Apostle of Faith, and, on the other hand, the historical Paul. Both Spinoza and Badiou offer complex philosophical readings of Paul that can be better understood when taking into consideration how they square with the image of Paul that has been constructed by the various theological traditions of Europe (i.e., the theological Paul or the Apostle of Faith), as well as the figure of Paul that is emerging due to the reconstructive work of contemporary historical-critical biblical scholarship. Both Spinoza and Badiou think highly of Paul, but for different reasons. Indeed, the two philosophers enlist Paul for their own political and philosophical ends. Spinoza and Badiou both offer readings of Paul that articulate their respective metaphysical/ontological views of the self. Spinoza presents a highly rationalistic reading of Paul. For Spinoza, Paul's rationalism seeks to elicit a certain pantheistic dissolution of the self. Badiou thinks Paul offers a revolutionary discourse, one that is politically charged, wherein the true, authentic subject emerges.

This essay takes for granted that the nearly two-thousand-year history of theological traditions of Europe have produced an image of Paul that is markedly distinct from the image of the historical Paul that is in the process of being recovered by certain biblical scholars, specifically those associated with the New Perspective on Paul, as well as postcolonial/empire-critical readings of Paul. ${ }^{2}$ The historical Paul's major opponent was the Roman Empire, and not Jewish Law, or internalintrospective matters relating to guilt, sin, grace, etc. The historical Paul fought the

\footnotetext{
${ }^{1}$ Spinoza, Tractatus Theologico-Politicus (hereafter Tractatus), ed. Jonathan Israel, trans. Michael Silverthorne and Jonathan Israel (Cambridge: Cambridge University Press, 2007). References to the Tractatus are to chapter followed by section number. Alain Badiou, Saint Paul: The Foundation of Universalism (hereafter SPFU), trans. Ray Brassier (Stanford: Stanford University Press, 2003). First published in French in 1997.

${ }^{2}$ In addition, one should add the important recent work of biblical scholars that take critically into account the role that assumptions about gender play in Paul's gospel, as well as in our own contemporary misunderstandings of the original intentions of the historical Paul.
} 
subhuman conditions caused by the insatiable lust for wealth and power of Imperial Rome, which sought to justify and promote itself by proclaiming across the empire its good news: the universal vision of salvation of the pax romana, offered only by the Imperial cult. Biblical scholar Dieter Georgi argues, I think rightly, that Paul borrowed some of his principal language and symbolism from the Roman emperor cult. For example, whereas terms like Lord (kyrios), gospel (euangélion), faith (pistis), the righteousness of God (dikaiosýne theou), peace (eirènè), and salvation (sōtèr) had been used originally in association with the religio-political power of the emperor, Paul reconfigures their meaning by applying them to a new master. ${ }^{3}$

Additionally, the historical Paul transformed the religio-political discourse of the Roman Imperial cult not only by re-applying its central concepts to the early Jesus-movement, but also by emphasizing the prophetic tradition of social justice (i.e., for the poor, the conquered, the colonized, and the enslaved) that is found within certain parts of the Hebrew Scriptures. Bruce Longenecker argues that it was out of the preferential option for the poor as promoted by biblical monotheism that "care for the poor was thought by Paul to be a necessary hallmark of the corporate life of Jesus-followers who lived in conformity with the good news of the early Jesusmovement." " Postcolonial readings of the historical Paul argue that his primary goal is the overturning of the conquering and colonizing Roman religio-political order through the building up of solidarity among all the ethne (nations, peoples) living under the heel of Imperial occupation.

In contrast to the historical Paul, the theological Paul (or the Apostle of Faith) refers to the image of Paul that has been constructed by the theological traditions of Europe, and especially by Augustine and Luther. This is the most commonly held view of Paul among believers in the various churches of the U.S. and Western Europe. An excellent example of the broad historical influence of the

\footnotetext{
${ }^{3}$ Dieter Georgi, Theocracy in Paul's Praxis and Theology, trans. David E. Green (Minneapolis: Fortress Press, 1991), 83-5.

${ }^{4}$ Bruce W. Longenecker, Remember the Poor: Paul, Poverty, and the Greco-Roman World (Grand Rapids: William B. Eedrmans, 2010), 1. See also Dieter Georgi, Remembering the Poor: The History of Paul's Collection for Jerusalem (Nashville: Abingdon, 1992).
} 
theological Paul can be found in Thomas Altizer's assertion that a "full and actual language of self-consciousness first historically appears in Paul's letters," and that "it is a negative language, indeed, a self-negating language, as the 'I' of self-

consciousness knows itself as a sinful and guilty conscience and consciousness, a carnal or fleshly 'I' that is wholly and totally imprisoned by sin." ${ }^{5}$ Unlike the historical Paul, the theological Paul is largely apolitical. Instead, the Apostle of Faith is primarily interested in internal-introspective concerns, with subjective spiritual matters involving personal interiority (i.e., sin, guilt, grace, personal salvation).

On this matter, biblical scholars associated with the New Perspective on Paul have provided much insight. ${ }^{6}$ Proponents of this school do not agree on all points. Following Stendahl, most argue that Paul's enemy was not Jews outside the Jesusmovement, but competing apostles within it, especially Jewish-Christians with the belief that non-Jewish converts must adhere to Jewish law (dietary restriction, circumcision, etc.). Many proponents of the New Paul Perspective argue that Paul did not preach that Jews can only find salvation in Christ, nor did he advocate the total abandonment of Jewish law. Lloyd Gaston, for example, argues not only that Paul did not encourage Jews to abandon the covenant, but that Paul remained a devout Jew throughout his life. ${ }^{7}$ Mark Nanos goes even farther when he argues that Paul was a Torah-observant Pharisee who expected Gentiles within the Jesusmovement to keep Jewish Laws. I think Nanos goes too far. On my view, Gaston's analysis seems more likely to represent the historical Paul; i.e., Paul's statements that promote a rejection of the Law are directed toward non-Jewish converts with the purpose of including them into the covenant, which had formerly been exclusive to the elect people of Israel, but becomes open to all nations/peoples (ethne) through

\footnotetext{
5 Thomas J. J. Altizer, "Paul and the Birth of Self-Consciousness," Journal of the American Academy of Religion 51, no. 3 (Sep., 1983): 359-370, here 359.

${ }^{6}$ See Krister Stendahl, Paul Among Jews and Gentiles, (Philadelphia: Fortress Press, 1976); E. P. Sanders, Paul and Palestinian Judaism (London and Philadelphia: Fortress Press, 1977), Paul, the Law, and the Jewish People (Minneapolis: Fortress Press, 1983); James D. G. Dunn, The New Perspective on Paul (Tübingen: Mohr Siebeck, 2005); N. T. Wright, Paul: in Fresh Perspective (Minneapolis: Fortress Press, 2005); John G. Gager, Reinventing Paul (New York: Oxford University Press, 2000); Stephen Westerholm, Perspectives Old and New on Paul: The "Lutheran" Paul and His Critics (Grand Rapids: Wm. B. Eerdmans Publishing Co., 2004); and Magnus Zetterholm, Approaches to Paul: A Student's Guide to Recent Scholarship (Minneapolis: Fortress Press, 2009).

${ }^{7}$ See Lloyd Gaston, "Paul and Torah," in Antisemitism and the Foundation of Christianity, ed. Alan Davies (New York: Paulist, 1979), 48-71.
} 
faithfulness in Christ. What follows is a discussion of the uses of Paul by Spinoza and Badiou, with a special attention paid to how these philosophical uses of Paul square with both the historical Paul and the image of Paul as the Apostle of Faith.

Spinoza's philosophical reading of Paul is a product of his radically new approach to the interpretation of scripture. Unlike his medieval and (early) Protestant forerunners, Spinoza distinguishes between biblical interpretation and theology. In Jewish, Christian, and Muslim exegetical traditions, "there is no distinction in the work of a patristic or medieval commentator between what we would call exegesis and theology." Spinoza's approach to biblical interpretation is informed by his profound commitment to rationalism, which takes for granted that all things can be fully understood by means of reason. Spinoza writes: "I hold that the [correct] method of interpreting Scripture, does not differ from the [correct] method of interpreting nature, but rather is wholly consistent with it."9

Spinoza's Tractatus, which confidently proclaims, "Paul teaches exactly what we want to affirm," is the first of many modern philosophical uses of Paul. ${ }^{10}$ Especially when it comes to biblical interpretation, for Spinoza (and many during the early Enlightenment), the reliance upon the guidance of the natural light of reason comes to replace the guidance of the Holy Spirit. That is, not only is the Bible believed to be fully in accordance with reason, but also that one can grasp the truths contained in the Bible (and elsewhere) by means of the natural light of reason. ${ }^{11}$ However, Spinoza clearly holds a lower estimation of the prophets of Hebrew scripture than he does the apostles of the New Testament. Unlike the discourse of the prophets, which "does not submit to [rational] discussion" and contains "only dogmas and commands," the apostles utilize "reason as if they were arguing rather than prophesying." 12

\footnotetext{
${ }^{8}$ Gregory W. Dawes, The Historical Jesus Question: The Challenge of History to Religious Authority (Louisville: Westminster John Knox Press, 2001), 56.

9 Tractatus, 7, 2. Brackets mine.

${ }^{10}$ Ibid., 3, 10. Other significant philosophical uses of Paul can be found in Locke, Berkeley, Kierkegaard, Nietzsche, and, more recently, Badiou, Agamben, and Žižek (among others).

11 4, 12: "the Bible fully endorses the natural light of reason and the natural divine law."

$1211,2$.
} 
Moreover, among the apostles, Spinoza singles out Paul by stressing Paul's status as the Apostle to the Nations. It is important to point out that a major assumption held by the theological traditions of Europe has been that Paul's conversion to the Christian faith corresponds with his rejection of the (supposed) particularism and legalism of the Jewish tradition (read: external, ritualistic religious concern), in favor of the universalism elicited by a Christian understanding of the grace of God. ${ }^{13}$ Spinoza's philosophical reading of Paul does not entirely deny this element of Christian supersessionism, but neither does Spinoza entirely support it. Instead, Spinoza reinterprets this long-held Christian theological assumption, and he does so by taking the meaning of Paul's conversion to represent the apostle's turn toward the guidance of the natural light of reason. Spinoza argues that the other apostles preached only to the Jews, who, in his estimation, did not value the Greek philosophical tradition as he thought they should. ${ }^{14}$ As the Apostle to the Nations, Paul alone could adapt his mind to the discourses of the Gentiles, and his discourse is therefore not entirely devoid of philosophy. For Spinoza, Paul is a radical proponent of religious liberty and freedom of conscience. Although he does not think of Paul as being a philosopher per se, Spinoza does argue that "none of the Apostles engaged with philosophy more than Paul."15 Spinoza's Paul promotes rational discourse for "all the nations," so that all people can "live good lives [not] because the law so commanded, but from a fixed conviction of the mind."16

Yovel Yirmiyahu has argued that the primary goal of Spinoza's Tractatus is "to secularize the modern state and purge it of allegiance to religious belief." ${ }^{17}$ It is certainly the case that Paul plays a preeminent role in Spinoza's attempt at a religiopolitical revolution in the Tractatus. Additionally, it seems to be the case that Spinoza thinks of Paul as being an ancient representative of Spinoza's metaphysical views, as

\footnotetext{
13 This element of Christian supersessionism (also known as rejection-replacement theology, diachronic historicism) likely does not reflect the historical Paul. For example,

14 Tractatus, 11, 9.

15 Ibid.

16 3, 10: "Paul concludes that God is the God of all nations, that is, God is equally well-disposed to all, and all men are equally under law and sin, and that is why God sent his Christ to all nations, to free all men equally from the servitude of the law, so that they would no longer live good lives because the law so commanded, but from a fixed conviction of the mind."

${ }^{17}$ Yovel Yirmiyahu, Dark Riddle: Hegel, Nietzsche, and the Jews (University Park, PA: Pennsylvania State University, 1998), 9.
} 
articulated in his other magnum opus, the Ethics. That is, while it is true that Spinoza thinks of Paul as being an ancient example of a paradigmatic rational opponent to unenlightened superstition, it is also the case that Spinoza thinks Paul is a proponent of a form of pantheism. Whereas the former position is articulated in several passages of the Tractatus, Spinoza suggests the former position in a comment made in a letter to his friend Henry Oldenburg. Spinoza writes: "I assert, as St. Paul and nearly all ancient philosophers said, though in another way, that all things are in God and move in God: and I dare even say that this assessment was to be found in all ancient Hebrews." ${ }^{18}$ Spinoza is referring here to the statement attributed to Paul in Acts 17:28: "In him we live and move and have our being." It is important to note that, perhaps even more explicitly than he does in the Tractatus, Spinoza is (in this letter) placing Paul on par with "nearly all ancient philosophers." This statement is made while Paul is in Athens, and it is directed to the Athenian philosophers. Paul is himself quoting from the ancient Cretan philosopher/poet Epimenides. As Spinoza argues in the Tractatus, Paul adapts his mind to philosophical discourse. But what is the end of having an enlightened mind, one that is open to philosophical discourse?

Along with Descartes and Leibniz, Spinoza is one of the great rationalists of early modern philosophy. But Spinoza is unique in the sense that he is an early rationalist philosopher who also promotes a form of pantheistic monism. Spinoza's political philosophy promotes freedom of conscience, at least generally speaking. ${ }^{19}$ Freedom of conscience should be allowed so that every person may think for themselves. Only when people think for themselves are they capable of being guided by the natural light of reason, which a rationalist philosopher like Spinoza takes to be the defining characteristic of being human. Pantheistic monism, the highest and most ancient truth, is grasped most clearly and distinctly by the natural light of reason. Yet (somewhat paradoxically) pantheistic monism is a metaphysical view wherein traditional assumptions about the inherent autonomy of the self make little sense. Spinoza thinks that, when seen from the standpoint of eternity (sub specie aeternitatis),

\footnotetext{
18 See Spinoza’s Works, vol. 2 (London: George Bell \& Sons, 1901), 298.

${ }^{19}$ Spinoza did not support the sort of religious liberty and separation of church and state that is promoted by the political philosophies of Locke and Jefferson, for example. That is, Spinoza's Republicanism allows for the state to interfere in religious matters to promote stability within society.
} 
the subjective, willful self (conatus) dissolves. This is the ancient truth that connects Paul with "nearly all ancient philosophers." ${ }^{20}$ In fact, Spinoza thinks this pantheistic view is "abandoned or falsified by later Christian theologians, whom Spinoza calls, with a certain wry historical irony, "New Christians." 21

Spinoza's metaphysics of self and his political theory are mutually expressed within his reading of Paul. With regard to Spinoza, Rebecca Goldstein insightfully comments that "the key to his political theory" is his desire to dissolve "all sectarian frames of reference, to point the way to a concept of personal identity in which the question of who is Jewish and who is not simply could not meaningfully arise."22 Goldstein takes Spinoza to be attempting to shed "as inessential all the passive markers of who he was, the accidents of his identity come to him by way of history." 23 For Spinoza, a certain objective self-estrangement that is found through the guidance of the natural light of reason is not only the highest and most enlightened religio-political goal, but also corresponds to his metaphysical position, which is pantheistic monism. Spinoza seeks "to transform the self so substantially as to change its very identity ... to the extent that we are rational, we, all of us, partake in the same identity." 24 This is especially profound given the degree to which the sort of religio-political conflicts involving freedom of conscience (or lack thereof) that plagued Europe during this period effected Spinoza's own familial and personal experience. After all, Spinoza's grandfather had fled the Inquisition in Portugal prior to settling in the relatively liberal environment of Holland. and Spinoza was himself excommunicated at an early age from the Jewish community in Holland.

Badiou's reading of Paul is similarly complex. It bears the influence of Lutheran theology, biblical scholarship after Hegel, and the demythologizing projects of Heidegger, Bultmann, and Bornkamm. Nietzsche influences Badiou's reading of Paul, albeit in a negative sense - and I say 'negative' because Badiou rejects the way

\footnotetext{
20 Spinoza's Works, 298.

${ }^{21}$ Yirmiyahu, Spinoza and Other Heretics, vol. 1 (Princeton: Princeton University Press, 1989), 238, note 20 .

22 Rebecca Goldstein, Betraying Spinoza: The Renegade Jew who Gave Us Modernity (New York: Schocken, 2006), 164.

23 Ibid., 166.

2468.
} 
in which Nietzsche understands Paul's conception of death. There is perhaps no other philosopher who targets Paul more vehemently than Nietzsche. Nietzsche thinks that it was with "Rabbinical impudence" that Paul "logicalized" the riddle of Jesus' death by introducing the doctrine of personal immortality. ${ }^{25}$ Nietzsche thinks Paul, as the inventor of Christianity, conquers (read: corrupts) Rome by seducing it with the promise of personal immortality. In contrast, Nietzsche thinks that Jesus, as the "bearer of glad tidings," was focused on the kingdom of heaven, which is here and now, a subjective experience of the heart - a way of life, rather than a set of beliefs (e.g., belief in personal immortality in the afterlife) ${ }^{26}$ Nietzsche blames Paul for attempting to negate and transcend death.

Contra Nietzsche, Badiou thinks Paul is neither a dialectician nor a logician. Badiou appreciates in Paul the invention of a new discourse and a new subjectivity, one "that is neither philosophical nor prophetic." ${ }^{27}$ In fact, Badiou calls Paul an antiphilosopher. ${ }^{28}$ For Badiou, Paul's conception of death does not signify the teaching of an otherworldly afterlife and the turning away from the body, life, and this world as it is in Nietzsche's critique of Paul. Badiou argues that Paul thinks of death in existential terms, as a subjective way of life - not by means of negation (in the Nietzschean sense), but in terms of extraction and subtraction. ${ }^{29}$ Badiou writes: "It is not a matter of denying death by preserving it, but of engulfing it, abolishing it." 30 Holsclaw has insightfully argued that "Badiou is against a Hegelian-Nietzschean capture of the resurrection as merely the sublimation of death, as the negation of negation (the object of Hegel's praise and Nietzsche's scorn). In this way Badiou argues for a de-dialecticized Christ-event, which separates out the cross and death as merely the site of the event, and resurrection as the event itself." ${ }^{31}$ On Badiou view, Paul's fable of Christ's death and resurrection creates a reconciliation between God

\footnotetext{
25 See Antichrist, \S 41, 42, 44, and 58.

26 Ibid, SS, 32-5.

27 SPFU, 46.

28 Ibid., 17.

29 Ibid., 73.

${ }^{30}$ Ibid., 72.

31 See Geoffrey Holsclaw, "Subjects between Death and Resurrection: Badiou, Žižek, and St. Paul," in Paul, Philosophy, and the Theopolitical Vision: Critical Engagements with Agamben, Badiou, Žižek, and Others, ed. by Douglas Harnik (Eugene: Cascade, 2010), 155-178; here 159.
} 
and humanity that "functions as a condition of immanence" for salvation, and "which is the eventual operation of resurrection." 32 Pauline discourse articulates two subjective paths in the inner experience of the self, one of life and one of death. ${ }^{33}$ Badiou sees in Pauline discourse, not the dialectical negation of death (ala Nietzsche), but instead the extraction or subtraction of death within the subject who is faithful to the truth-event. In Paul's case, the truth-event is his conversion, which, for Badiou, means Paul's abandonment or overcoming of Jewish and Roman law (death) and an acceptance of Christian grace by means of the subject's fidelity to the resurrection-event (life).

On Badiou's view, within Pauline discourse the power of grace eradicates the negativity that is associated with sin and death, both being products of the subject's adherence to law. ${ }^{34}$ Unlike certain contemporary biblical scholars (i.e., the New Perspective on Paul), Badiou takes for granted Paul's conversion, and he assumes this means Paul abandons Jewish law. Badiou's reading of Paul involves a unique type of Christian supersessionism; i.e., a reinterpretation of a major component of (what I referred to above as) the theological Paul. For Badiou, "only the law fixes the object of desire, binding desire to it regardless of the subject's will." 35 Badiou thinks that the state of grace, as discussed in Paul's writings, represents a non-philosophical attempt to articulate the liberation of the subject by means of its fidelity to a truthevent, one in which the system that fixes desire as repetitive and autonomous (i.e., bondage to law, sin, and death) is disrupted by a "multiplicity that, exceeding itself, upholds universality (i.e., the ${ }^{36}$

Badiou highlights the political implications at work in Saul's conversion to Paul. ${ }^{37}$ Saul, the radically obedient defender of the religio-political order (i.e., Jewish

\footnotetext{
32 See SPFU, 68-71.

33 Ibid., 78.

${ }^{34}$ Ibid., 72

35 Ibid., 79.

36 Ibid., 78.

37 This narrative is told in Acts 9, but is absent from the authentic Pauline epistles. In Galatians 1, which is an authentic Pauline epistle, Paul does mention: "You have heard, no doubt, of my earlier life in Judaism. I was violently persecuting the church of God and was trying to destroy it." But this does not prove that Paul, either in part or entirely, abandoned Judaism. His later life in "the church of God" may have been viewed by Paul as a calling, and not a conversion (in the sense of abandoning Judaism) per se.
} 
legalism and Roman oppression), becomes Paul, the proponent of a new Christian order. Moreover, Badiou takes Paul's conversion as a rejection of not only Jewish law, but also (what he calls) Roman legalism. That is, Badiou highlights the political implications he thinks undergirds Paul's claim to be the "Apostle to the Nations." 38 Badiou writes: "although himself a Roman citizen, and proud of it, Paul will never allow any legal categories to identify the Christian subject. Slaves, women, people of every profession and nationality will therefore be admitted without restriction or privilege." 39 To a significant extent Badiou’s analysis aligns with postcolonial reconstructions of the historical Paul, which argue that his primary goal is the overturning of the conquering and colonizing Roman religio-political order through the building up of solidarity among all the ethne (nations, peoples) living under the heel of Imperial occupation. The imperial cult is based on dichotomies of domination/submission, free/slave, man/woman, man/child, and Paul's gospel attempts to overthrow these hierarchical systems of power that undergird the Roman Empire by creating a new religio-political order where all members are equals before God.

Badiou's use of Paul plays a significant role within his broader philosophy of the event. For Badiou, the "Paulinian wager is that a discourse can exist which configures the real as a pure event and which, from that point on, addresses everyone without exception." ${ }^{\prime 4}$ Badiou is particularly interested in Paul because he thinks Pauline discourse articulates the process by which the authentic militant subject can emerge via its fidelity to a truth-event. In Paul's case the truth-event is the grace afforded by belief in the salvific power of the resurrection-event as a subjective experience that liberates from bondage to law (i.e., sin and death). Badiou is neither concerned with 'the historical Jesus', nor with resurrection as a historical fact. Instead, he is interested in the fable that Paul, the "poet-thinker of the event," is inspired to invent. ${ }^{41}$ Badiou does not particularly care about the truth or falsity of the

\footnotetext{
38 Romans 11:13: "I am the Apostle to the Nations." All translations from the New Testament in the present essay are from the New Revised Standard Version.

${ }^{39}$ Ibid., 13-4.

40 See St. Paul Among the Philosophers, ed. John D. Caputo and Linda Martin Alcoff (Bloomington, IN: Indiana University Press, 2009), 32.

${ }^{41}$ SPFU, 2.
} 
content of the fable, but only with the efficacy of its structural form. Paul's fable of the Cross is efficacious because it encourages the emergence of the "militant figure" (la figure militante). ${ }^{42}$

So how does Badiou's reading square with the one put forward by Spinoza? Spinoza's is the first modern philosophical use of Paul, and Badiou's is one of the most recent. Despite being separated by over three hundred, both Spinoza's and Badiou attempt to enlist Paul for their own political and philosophical ends.

Nevertheless, regarding the historical Paul, the philosophical uses of Paul by Spinoza and Badiou are more compatible with postcolonial/empire critical readings of Paul, than they are with the New Perspective on Paul. Despite the fact both Spinoza and Paul reconstruct something of the radical religio-political core of the historical Paul, it is nevertheless the case that they both do so by taking for granted some core elements of the theological Paul. Regarding the metaphysics of the self that are at play in their two readings of Paul, the philosophers take contrary positions.

On the one hand, Badiou thinks Pauline discourse offers the possibility of the emergence of an authentic subject by means of an unpredictable and incalculable truth-event, which interrupts the autonomous repetition of law and sin. Badiou writes: "What interests me in Saint Paul is the idea - very explicit in his writings that the becoming of a truth, the becoming of a subject, depend entirely on a pure event, which is itself beyond all predictions and calculations that our understanding is capable of." ${ }^{43}$ Specifically, Badiou argues that Paul, the "militant figure," emerges as a result of the universalizing truth procedure of the event (i.e., the resurrection-event), which is open to all, and calls all equally to a new life. ${ }^{44}$ Badiou argues that Paul's conversion leads to a radical opening up of monotheism to all, as a subversion of

\footnotetext{
42 Ibid.

${ }^{43}$ Badiou, Ethics: An Essay on the Understanding of Evil, trans. Peter Hallward (London and Brooklyn: Verso, 2012), 123. Emphasis mine.

${ }^{44}$ Romans 6:6-8: "We know that our old self was crucified with him so that the body of sin might be destroyed, and we might no longer be enslaved to sin. For whoever has died is freed from sin. ${ }^{8}$ But if we have died with Christ, we believe that we will also live with him."
} 
both Jewish and Roman law, and that this is Paul's "genuinely revolutionary conviction." 45

On the other hand, for Spinoza, Paul's rationalism seeks to elicit a certain dissolution of the self. Spinoza offers an account of Paul that portrays the apostle as a rational proponent of a sort of pantheistic monism, wherein the subjective, willful self dissolves when seen under the objective light of eternity. Within Spinoza's reading of Paul individual subjectivity is overcome by absolute rational objectivity. Spinoza thinks Paul shares his metaphysical vision, and in this metaphysical vision there is a profound anonymity, one that is comparable to a story in the Gospel of Matthew. In this story, some Sadducees ask Jesus about the resurrection, which is a belief that the Sadducees denied. The Sadducees propose the following question to Jesus:

Moses said, "If a man dies childless, his brother shall marry the widow, and raise up children for his brother." Now there were seven brothers among us; the first married, and died childless, leaving the widow to his brother. The second did the same, so also the third, down to the seventh. Last of all, the woman herself died. In the resurrection, then, whose wife of the seven will she be? For all of them had married her.'

Jesus responds by saying:

You are wrong, because you know neither the scriptures nor the power of God. For in the resurrection they neither marry nor are given in marriage, but are like angels in heaven. ${ }^{46}$

Both Spinoza and Badiou admire the universalism of the Apostle to the Nations, and both reinterpret and incorporate this universalism within their respective politics of the self, albeit in contrary ways. For Badiou, Paul offers a non-philosophical blueprint of a discourse that evokes the emergence of the subject as the militant figure. For Spinoza, Pauline discourse seeks to elicit a rationalistic dissolution of the

45 SPFU, 76: "That there is but a single God must be understood not as a philosophical speculation concerning substance or the supreme being, but on the basis of a structure of address. The One is that which inscribes no difference in the subjects to which it addresses itself."

${ }^{46}$ Matthew 22:24-30. 
subject, one which also points to the highest political goal per the particular historico-political context that Spinoza seeks to challenge with his Pauline political philosophy. 


\section{Bibliography}

Altizer, Thomas J. J. "Paul and the Birth of Self-Consciousness." Journal of the American Academy of Religion 51, no. 3 (Sep., 1983): 359-370.

Badiou, Alain. Saint Paul: The Foundation of Universalism. Translated by Ray Brassier. Stanford: Stanford University Press, 2003.

. St. Paul Among the Philosophers. Edited by John D. Caputo and Linda Martin Alcoff. Bloomington, IN: Indiana University Press, 2009.

. Ethics: An Essay on the Understanding of Evil. Translated by Peter Hallward. London and Brooklyn: Verso, 2012.

Dawes, Gregory W. The Historical Jesus Question: The Challenge of History to Religious Authority. Louisville: Westminster John Knox Press, 2001.

Dunn, James D. G. The New Perspective on Paul. Tübingen: Mohr Siebeck, 2005.

Gager, John G. Reinventing Paul. New York: Oxford University Press, 2000.

Gaston, Lloyd Gaston. "Paul and Torah," in Antisemitism and the Foundation of Christianity. Edited by Alan Davies. New York: Paulist, 1979.

Georgi, Dieter. Theocracy in Paul's Praxis and Theology. Translated by David E. Green (Minneapolis: Fortress Press, 1991). . Remembering the Poor: The History of Paul's Collection for Jerusalem (Nashville: Abingdon, 1992).

Goldstein, Rebecca. Betraying Spinoza: The Renegade Jew who Gave Us Modernity. New York: Schocken, 2006.

Holsclaw, Geoffrey. "Subjects between Death and Resurrection: Badiou, Žižek, and St. Paul," in Paul, Philosophy, and the Theopolitical Vision: Critical Engagements with Agamben, Badiou, Žǐ̌ek, and Others. Edited by Douglas Harnik. Eugene: Cascade, 2010.

Longenecker, Bruce W. Remember the Poor: Paul, Poverty, and the Greco-Roman World. Grand Rapids: William B. Eedrmans, 2010.

Nietzsche, Friedrich. The Anti-Christ, Ecce Homo, Twilight of the Idols and Other Writings. Translated by Judith Norman. Edited by Aaron Ridley and Judith Norman. Cambridge: Cambridge University Press, 2005. 
Sanders, E. P. Paul and Palestinian Judaism. London and Philadelphia: Fortress Press, 1977. . Paul, the Law, and the Jewish People. Minneapolis: Fortress Press, 1983.

Stendahl, Krister. Paul Among Jews and Gentiles. Philadelphia: Fortress Press, 1976.

Spinoza, Benedict de. Tractatus Theologico-Politicus. Edited by Jonathan Israel. Translated by Michael Silverthorne and Jonathan Israel. Cambridge: Cambridge University Press, 2007.

_. Spinoza's Works, vol. 2 (London: George Bell \& Sons, 1901),

Westerholm, Stephen. Perspectives Old and New on Paul: The "Lutheran" Paul and His Critics. Grand Rapids: Wm. B. Eerdmans Publishing Co., 2004.

Wright, N. T. Paul: in Fresh Perspective. Minneapolis: Fortress Press, 2005.

Yirmiyahu, Yovel. Spinoza and Other Heretics, vol. 1. Princeton: Princeton University Press, 1989.

. Dark Riddle: Hegel, Nietasche, and the Jews. University Park, PA: Pennsylvania State University, 1998.

Zetterholm, Magnus. Approaches to Paul: A Student's Guide to Recent Scholarship. Minneapolis: Fortress Press, 2009. 